Biochimica et Biophysica Acta, 312 (1973) 392-398

(C) Elsevier Scientific Publishing Company, Amsterdam - Printed in The Netherlands

BBA 97709

\title{
INTERRELATIONSHIP BETWEEN AMINO ACID POOLS AND PROTEIN SYNTHESIS IN THE RAT SUBMANDIBULAR GLAND
}

WALTHER J. VAN VENROOIJ*, ANNERIEK H. KUIJPER-LENSTRA and MEBIUS F. KRAMER

Laboratorium voor Histologie en Celbiologie, Faculteit der Geneeskunde, Rijksuniversiteit Utrecht, Utrecht (The Netherlands)

(Received January 18th, 1973)

\section{SUMMARY}

The uptake and incorporation in vitro of radioactive leucine in rat submandibular gland fragments have been studied. Both uptake and incorporation were found to be influenced by the concentration of leucine in the medium.

By means of a cold-wash procedure we were able to distinguish between extraand intracellular free amino acids. We found that it takes 10 to $15 \mathrm{~min}$ for the radioactive leucine to reach maximal concentration in the intracellular soluble amino acid pool. Nevertheless their incorporation into protein becomes linear shortly after the start of incubation in the radioactive medium. We did not find any sign of a decreasing rate of protein synthesis during the incubation. In chase-type experiments, the incorporation of radio-active leucine stops immediately when the labelled medium is replaced by unlabelled medium, though the free, intracellular amino acid radioactivity declines only slowly. These results confirm earlier reports, that in vitro, under conditions of sufficient extracellular amino acid supply, the amino acid molecules incorporated into protein are not selected from the intracellular pool.

\section{INTRODUCTION}

The relationship between the extracellular levels of amino acids, their uptake into the animal cell and incorporation into protein is not clear. The role of the large intracellular amino acid pool in cellular metabolism has not been defined, but one of its functions has been assumed to be that of an obligatory precursor pool for protein synthesis. This assumption has been seriously questioned as a result of studies with diaphragm $^{1,2}$, heart ${ }^{2}$, the extensor digitorum longus muscle ${ }^{3,4}$, jejunum $^{5}$, and pancreas $^{6}$ of the rat.

In our studies in vitro with fragments of the rat submandibular gland we measured the appearance of radioactive leucine from the medium into the intracel-

* Present address: Laboratorium voor Biochemie, Universiteit van Nijmegen, Geert Grooteplein $\mathbf{N} 21$ Nijmegen, The Netherlands. 
lular amino acid pool and into cellular protein. In agreement with our earlier results with rat pancreas ${ }^{6}$ and those of other laboratories ${ }^{1-5}$, we found that the amino acids used for protein synthesis are utilized directly from the extracellular fluid, bypassing the intracellular pool.

\section{MATERIALS AND METHODS}

L-[U- $\left.{ }^{14} \mathrm{C}\right]$ Leucine (spec. act. $333 \mathrm{Ci} / \mathrm{mole}$ ), [U- $\left.{ }^{14} \mathrm{C}\right]$ sorbitol (spec. act. 7.0 $\mathrm{Ci} / \mathrm{mole}$ ) and L- $\left[4.5-{ }^{3} \mathrm{H}_{2}\right]$ leucine (spec. act. $1000 \mathrm{Ci} / \mathrm{mole}$ ) were obtained from the Radiochemical Centre, Amersham. Unlabelled amino acids were from Sigma Chem. Co. and Fluka. Young adult male rats (about $200 \mathrm{~g}$ ) from the Wistar strain and obtained from TNO, Holland, were fed ad libitum with pelleted food until $24 \mathrm{~h}$ before the experiment.

\section{The incubation}

After decapitation the submandibular glands 'were cut out and fragmented with the TC-2 Sorvall Tissue Sectioner into pieces of $1 \mathrm{~mm}^{3}$ each. The $1 \mathrm{~mm}^{3}$ fragments of both glands of one animal were preincubated at $37^{\circ} \mathrm{C}$ for $10 \mathrm{~min}$ in a conical flask containing $4 \mathrm{ml} \mathrm{Krebs-Ringer} \mathrm{incubation} \mathrm{medium.} \mathrm{The} \mathrm{complete} \mathrm{composition} \mathrm{of}$ the incubation medium has been described ${ }^{6}$. After the preincubation the pieces of submandibular gland tissue were divided, and each portion of about $50 \mathrm{mg}$ of tissue was transferred to another flask containing $2 \mathrm{ml}$ complete medium and the radioactive compounds for the experiment (to final concentrations of $0.5 \mu \mathrm{Ci} / \mathrm{ml}$ for $\left[{ }^{14} \mathrm{C}\right]$ sorbitol and $\left[{ }^{14} \mathrm{C}\right]$ leucine, and of $5.0 \mu \mathrm{Ci} / \mathrm{ml}$ for $\left[{ }^{3} \mathrm{H}\right]$ leucine). All experiments were carried out under continuous gassing with a mixture of $95 \% \mathrm{O}_{2}$ and $5 \% \mathrm{CO}_{2}$ and gentle shaking at $37^{\circ} \mathrm{C}$.

In short, unless a description is given, the procedures used were as follows: at the end of the incubation the tissue fragments were washed three times with $5 \mathrm{ml}$ of ice-cold medium plus unlabelled compound $(8 \mathrm{mM})$, each time for $5 \mathrm{~min}$, to remove the extracellular amino acid while the intracellular amino acid is presumed to be preserved $^{4,6}$. In some experiments the tissue fragments were blotted with filter paper to preserve the extra- and intracellular amino acid. Then they were homogenized and the filtered homogenate was divided in equal portions for determining the DNA quantity $^{7}$ and the radioactivity in the trichloroacetic acid-soluble and -insoluble fractions ${ }^{6}$.

Trichloroacetic acid-soluble radioactivity per $\mu \mathrm{g}$ DNA, determined in the cold-washed fragments, is used as a measure of the intracellular radioactive amino acid, while the difference in trichloroacetic acid-soluble radioactivity between blotted and cold-washed fragments is used as a measure of the extracellular radioactive amino acid.

\section{Paper chromatography}

The trichloroacetic acid-soluble and -insoluble radioactivity was analyzed on Whatman $3 \mathrm{MM}$ paper, the latter after hydrolysis with $6 \mathrm{M} \mathrm{HCl}$. The eluant used was $n$-butanol-acetic acid-water $(4: 1: 5, \mathrm{v} / \mathrm{v} / \mathrm{v})$. Paper chromatographic analysis showed that more than $95 \%$ of the hydrolyzed trichloroacetic acid-insoluble ${ }^{3} \mathrm{H}$ or ${ }^{14} \mathrm{C}$ radioactivity was in the leucine spot. 
When $\left[{ }^{3} \mathrm{H}\right]$ leucine was used we found more than $90 \%$ of the trichloroacetic acid-soluble, intracellular radioactivity in the free leucine spot. In the case of $\left[{ }^{14} \mathrm{C}\right]$ leucine, however, about $30 \%$ of the trichloroacetic acid-soluble radioactivity was found to be present as a slower moving product that could not be identified as leucine. Although most experiments were performed using $\left[{ }^{3} \mathrm{H}\right]$ - as well as $\left[{ }^{14} \mathrm{C}\right]$ leucine, we did not observe any difference in our results between the two precursors.

\section{RESULTS}

\section{Effects of variations in medium amino acid concentration}

Fragments of submandibular tissue were incubated for $15 \mathrm{~min}$ with a constant (plasma) level of ${ }^{12} \mathrm{C}$-labelled amino acids (except leucine) to which $\left[{ }^{14} \mathrm{C}\right]$ leucine and a varying concentration of $\left[{ }^{12} \mathrm{C}\right]$ leucine was added. In all incubations we added that amount of $\left[{ }^{14} \mathrm{C}\right]$ leucine to the medium needed to reach a specific radioactivity of $6.0 \mathrm{Ci} / \mathrm{mole}$.

As is shown in Fig. 1 the uptake and incorporation of leucine into the cells depends on the concentration of the leucine in the medium. While the amount of free (trichloroacetic acid-soluble) leucine in the cells increases with increasing medium concentration, the leucine incorporation into protein is at most maximal at a medium leucine concentration between $0.1 \mathrm{mM}$ and $0.3 \mathrm{mM}$. We therefore decided for our further experiments to preincubate and incubate at plasma amino acid concentrations.

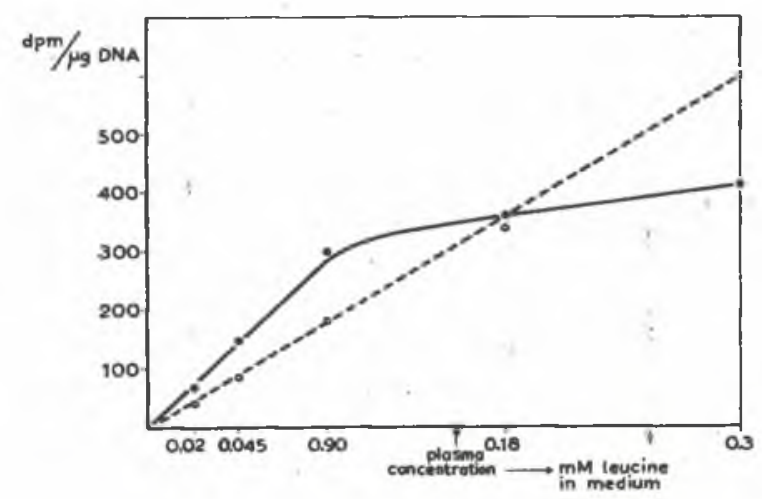

Fig. 1. The effect of increasing concentration of extracellular leucine on its uptake and incorporation in vitro. Fragments of rat submandibular gland tissue were incubated in $2 \mathrm{ml}$ of complete medium with only the leucine concentration varying as indicated. After 10 min the fragments were transferred to another flask with $2 \mathrm{ml}$ of medium containing the selected $\left[{ }^{12} \mathrm{C}\right]$ leucine concentration plus that (trace) amount of $\left[{ }^{14} \mathrm{C}\right]$ leucine needed to reach a specific radioactivity of $6.0 \mathrm{Ci} / \mathrm{mole}$. After 15-min incubation the fragments were cold washed and the trichloroacetic acid-insoluble (O-C) and trichloroacetic acid-soluble (O- - 0 ) radioactivity determined.

\section{Kinetics of intracellular uptake and incorporation}

In a previous paper we demonstrated that the blotting procedure preserves both intracellular and extracellular free amino acids of incubated pancreas tissue fragments. On the other hand the cold-wash procedure removes most of the extracellular material ${ }^{6}$. We found similar results with submandibular tissue incubated with either $\left[{ }^{14} \mathrm{C}\right]$ sorbitol or $\left[{ }^{14} \mathrm{C}\right]$ leucine. After various times of incubation, fragments 
were taken out and blotted or cold washed. As is shown in Fig. 2A, the sorbitol enters the extracellular space of the tissue fragments very rapidly, reaching a saturation level after about $15 \mathrm{~min}$ of incubation (the extracellular space appears to be $34 \%$ ( \pm 3 ) of the tissue wet weight). The extracellular leucine accumulates to a saturated level even more rapidly while the soluble intracellular amino acid radioactivity increases continuously during the $30 \mathrm{~min}$ of incubation (Fig. 2A). The incorporation of radioactive leucine into protein increased, after a lag time of about $2 \mathrm{~min}$, linearly up to at least $30 \mathrm{~min}$ of incubation (Fig. 2B).

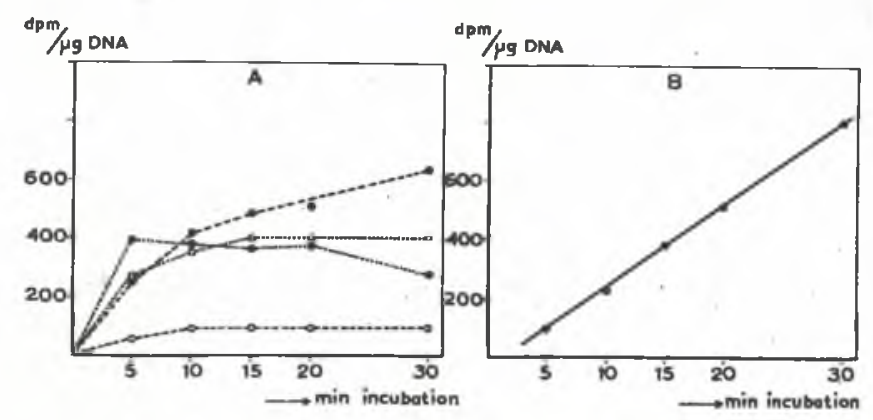

Fig. 2. Uptake into tissue water of sorbitol and leucine in vitro. (A) Submandibular tissue fragments were preincubated for $10 \mathrm{~min}$ and then incubated in medium containing $\left[{ }^{14} \mathrm{C}\right]$ sortibol or $\left[{ }^{14} \mathrm{C}\right]-$ leucine. $\mathrm{O}$. . . O, uptake of $\left[{ }^{14} \mathrm{C}\right]$ sorbitol measured after blotting of the tissue fragments; $\mathrm{O}---\mathrm{O}$, uptake of $\left[{ }^{14} \mathrm{C}\right]$ sorbitol measured after the cold-wash procedure; - - -, uptake of $\left[{ }^{14} \mathrm{C}\right]$ leucine measured after the cold-wash procedure; $\cdots$, uptake of $\left[{ }^{14} \mathrm{C}\right]$ leucine into extracellular tissue space calculated by subtracting the amount of soluble radioactivity after the cold washings from that remaining after the blotting procedure. (2B) Incorporation of $\left[{ }^{14} \mathrm{C}\right]$ leucine into protein as a function of the incubation time.

\section{Effect of the incubation time on the rate of protein synthesis}

The following experiments were performed in order to test whether the initial rate of protein synthesis decreases during the first $\mathbf{4 0} \mathrm{min}$ of incubation of the gland fragments. After the normal preincubation of $10 \mathrm{~min}$, gland fragments were transferred to another vial with $2 \mathrm{ml}$ fresh complete medium. Radioactive leucine was added after 0,5 and $10 \mathrm{~min}$ additional incubation. The results of one of these experiments are shown in Fig. 3. It appeared that the initial rate of protein synthesis does not change when the preincubation time is extended.

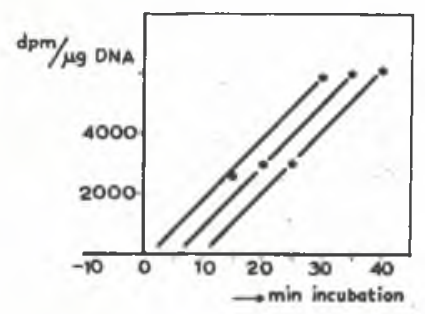

Fig. 3. The effect of preincubation time on the incorporation of $\left[{ }^{3} \mathbf{H}\right]$ leucine. Rat submandibular fragments were preincubated for 10,15 and $20 \mathrm{~min}$, respectively, and then $\left[{ }^{3} \mathrm{H}\right]$ leucine was added. The trichloroacetic acid-insoluble radioactivity was measured at the indicated time intervals. 
Effect of a chase on the trichloroacetic acid-soluble and insoluble intracellular radioactivity

Fragments of the rat submandibular glands were preincubated for $10 \mathrm{~min}$ in $5 \mathrm{ml}$ complete medium. Then the fragments were transferred to another flask containing $5 \mathrm{ml}$ complete medium and $2.5 \mu \mathrm{Ci}\left[{ }^{14} \mathrm{C}\right]$ leucine or $25 \mu \mathrm{Ci}\left[{ }^{3} \mathrm{H}\right]$ leucine. After incubation for $10 \mathrm{~min}$ a first portion of fragments was taken out and cold washed as described. After 20 min of incubation the other fragments were taken out, quickly rinsed twice in $10 \mathrm{ml}$ complete medium at $37^{\circ} \mathrm{C}$ to remove adhering radioactivity and divided into four portions. One portion was cold washed and analyzed. A second portion was reincubated for another $10 \mathrm{~min}$ in $2 \mathrm{ml}$ complete medium with the radioactive amino acid present in the concentration described above. The two other portions were each incubated in $2 \mathrm{ml}$ of complete medium without radioactive amino acid (all unlabelled amino acids still being present in plasma concentration) for a subsequent 10 and $20 \mathrm{~min}$. 'The radioactivity in all tissue fragments was measured after the cold-wash procedure. Fig. 4 shows that the rise in the amount of radioactive protein stops abruptly after the onset of the chase, whereas the intracellular trichloroacetic acid-soluble radioactivity only leaks slowly into the medium, in which it is rapidly diluted.
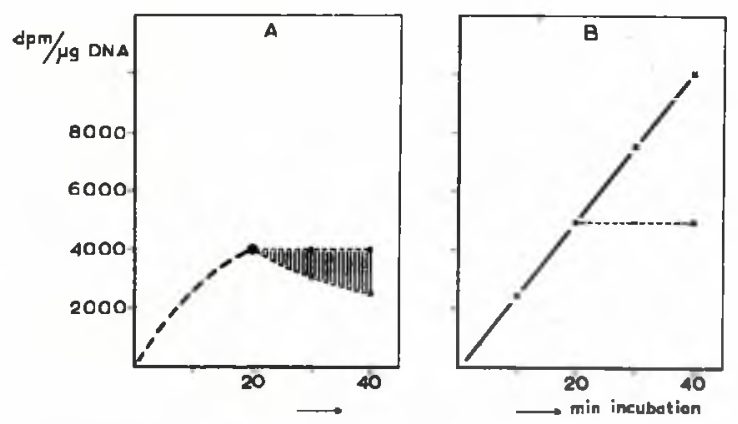

Fig. 4. Effect of a non-radioactive chase on intracellular $\left[{ }^{3} \mathrm{H}\right.$ ]leucine content and incorporation in vitro. Techniques used are described in the text. (A) - - , trichloroacetic acid-soluble intracellular $\left[{ }^{3} \mathrm{H}\right]$ leucine influxed into the cells during incubation in radioactive medium. $\times-\ldots$, , trichloroacetic acid-soluble $\left[{ }^{3} \mathbf{H}\right.$ ]leucine remaining in the cells during a non-radioactive chase. Hatched area: trichloroacetic acid-soluble [ $\left.{ }^{3} \mathrm{H}\right]$ leucine in extracellular tissue space and in medium. (B) $\times-\times,\left[{ }^{3} \mathbf{H}\right]-$ leucine incorporated into trichloroacetic acid-insoluble material during incubation in radioactive medium. $x-\cdots \times,\left[{ }^{3} \mathbf{H}\right]$ leucine incorporated into trichloroacetic acid-insoluble material during a non-radioactive chase from 20 min onwards.

\section{DISCUSSION}

Under the conditions of our experiments the graph of the net uptake of radioactive leucine per $\mu \mathrm{g}$ of DNA into the intracellular amino acid pool, estimated from the amount of trichloroacetic acid-soluble radioactivity that remains in the tissue after the cold-wash procedure ${ }^{4,6}$, can be considered to reflect the course of the specific radioactivity of this pool, provided the pool size is about constant. Many authors, working with various tissues in vitro ${ }^{1-6,8,9}$, observed the gradual increase of the specific radioactivity of the intracellular amino acid pool as shown in Fig. 2A.

Even though the specific radioactivity of the intracellular amino acid pool 
increased, the rate of incorporation of radioactivity into protein, which depends directly on the specific radioactivity of the precursor pool ${ }^{10}$, showed no increase (Fig. 2B). From the fact that the incorporation of radioactivity starts to be linear 2 min after the onset of radioactive incubation one can conclude that the cells select their amino acids for protein synthesis from a pool in which maximal specific radioactivity is reached nearly instantly, e.g. the extracellular pool which is in rapid equilbrium with the medium.

One could argue that the linear incorporation of radioactivity is the result of opposite influences, the effect of the increasing specific radioactivity of the intracellular pool being undone by a decrease in the rate of protein synthesis due to suboptimal conditions of the system in vitro. This argument is ruled out by the experiment presented in Fig. 3. This experiment indicates that the capacity of the fragments of the submandibular gland to synthesize protein is not impaired during the incubation period of the original experiments and longer, up to $50 \mathrm{~min}$ of preincubation and incubation.

The experiments so far discussed (Figs 2 and 3 ) favour the assumption that intracellular amino acid is not the main source of the precursor leucine. More evidence to this hypothesis is given by the chase experiments ${ }^{3-6}$ depicted in Fig. 4 . They show that in spite of the intracellular presence of radioactive leucine this apparently is not used for protein synthesis when the radioactive extracellular medium is replaced by fresh unlabelled medium. In fact they are exchanged with the unlabelled leucine in the medium.

We conclude that under conditions of a sufficient extracellular amino acid supply, rat submandibular gland cells in vitro incorporate leucine into protein not from a general intracellular store, but from a pool which is in rapid equilibrium with the extracellular pool if not from the latter itself. The same conclusion has been reached already for rat diaphragm and isolated lymph node cells with proline, glycine, and leucine ${ }^{1}$, for rat muscle with leucine and glycine ${ }^{3,4}$, for rat intestine with leucine ${ }^{5}$, for rat pancreas with leucine and lysine ${ }^{6}$, and for leucocytes with leucine ${ }^{9}$.

What does this mean for studies in which the amount of incorporation of radioactive amino acid is used as a measure of the rate of protein synthesis? We now know that in a variety of cell systems in vitro there is no need to determine the specific radioactivity of the intracellular pool of the amino acid. It would seem sufficient in these cases to determine the specific radioactivity of the extracellular amino acid. However, the situation is complicated by at least two conceivable factors: (a) The extracellular pool could be compartmentalized into a part rapidly exchanging and another part more bound and fixed ${ }^{4}$. Then the specific radioactivity of the total extracellular pool is probably of no value. (b) The extracellular labelled amino acids used for protein synthesis may be diluted with unlabelled amino acids in efflux from the cell. This dilution, taking place just at the outside of the cellular membrane, is difficult to measure. If it varies under different circumstances, e.g. as a result of differences in the extent of intracellular protein catabolism, the specific radioactivity of the extracellular precursor is not a constant factor.

In view of these two reflections and of the lack of knowledge about the situation in vivo, we think that the specific radioactivity of the aminoacyl-tRNA needs to be known. Only then can valuable conclusions about the rate of protein synthesis 
in vivo, as well as in vitro, be drawn.

This demand is not met by many investigations on protein synthesis.

\section{ACKNOWLEDGEMENTS}

We thank Miss G. W. Best for technical assistance and Drs C. Poort and M T. Jansen for their valuable discussions.

This research was in part supported by the Netherlands Foundation for Chemical Research (SON) with financial aid from the Netherlands Organization for the Advancement of Pure Research (ZWO).

\section{REFERENCES}

1 Kipnis, D. M., Reis, E. and Helmreich, E. (1961) Biochim. Biophys. Acta 51, 519-524

2 Manchester, K. L. and Wool, 1. G. (1963) Biochem. J. 89, 202-209

3 Hider, R. C., Fern, E. B. and London, D. R. (1969) Biochem. J. 114, 171-178

4 Hider, R. C., Fern, E. B. and London, D. R. (1971) Biochem. J. 121, 817-827

5 Fern, E. B., Hider, R. C. and London, D. R. (1971) Eur. J. Clin. Invest. 1, 211-215

6 Venrooij, W. J. van, Poort, C., Kramer, M. F. and Jansen, M. T. (1972) Eur. J. Biochem. 30, 427-433

7 Burton, K. (1956) Biochem. J. 62, 315-323

8 Berg, W. E. (1968) Exp. Cell Res. 49, 379-395

9 Winkler, K. (1972) Hoppe-Seyler's Z. Physiol. Chem. 353, 782-786

10 Reboud, J. P., Marchis-Mouren, G., Pasero, L., Cozzone, A. and Desnuelle, P. (1966) Biochim. Biophys. Acta 117, 351-367 